\title{
Efek penambahan oats pada formulasi cookies gandum dilihat dari karakteristik fisik dan sensorinya
}

Effect of oats addition in wheat cookies formulation seen from its physical and sensory characteristics

\author{
Monika Rahardjo $^{\left.1^{*}\right)}$, Ristia Widi Astuti ${ }^{2)}$, Dhanang Puspita ${ }^{1)}$, Monang Sihombing ${ }^{1)}$ \\ ${ }^{1}$ Program Studi Teknologi Pangan, Fakultas Kedokteran dan Ilmu Kesehatan, \\ Universitas Kristen Satya Wacana \\ ${ }^{2}$ Program Studi Gizi, Fakultas Kedokteran dan Ilmu Kesehatan, \\ Universitas Kristen Satya Wacana \\ Email: monika.rahardjo@uksw.edu; 472015031@ student.uksw.edu; \\ dhanang.puspita@uksw.edu; monang.sihombing@uksw.edu \\ Informasi Artikel: \\ Dikirim: 22/11/2019; ditinjau: 23/11/2019; disetujui: 23/01/2020
}

\begin{abstract}
This research aims to determine the effect of oats addition in wheat cookies formulation seen from physical and sensory characteristics. Six formulations used in this research consist of wheat flour and oats mixture namely Control (100\%:0\%), Formulation 1 (80\%:20\%), Formulation 2 (60\%:40\%), Formulation 3 (40\%:60\%), Formulation 4 (20\%:80\%), and Formulation 5 (0\%:100\%). Based on analysis of variance result at $\alpha$ $=5 \%$, there was a significant difference in the value of hardness and work from control and all variation of cookies' formulation. It was also found that the decreasing composition of wheat flour and increasing composition of oats caused a decrease in the value of hardness and work. The addition of oats in the formulation of wheat cookies increases the level of brightness $(L)$, decreases the value of $a^{*}$ (red tone), and increases the value of $b^{*}$ (yellow tone) of cookies. From sensory evaluation, compared to controls, the addition of oats in the formulation increased the acceptance rating for color parameter for all formulation, taste parameter for Formulation 2 until 5, and overall parameter for Formulation 2 and 3, while for the texture parameter, the addition of oats did not provide an increased in the acceptance rating.
\end{abstract}

Keywords: cookies, oats, physical characteristic, sensory characteristic, wheat

\begin{abstract}
ABSTRAK
Tujuan penelitian ini adalah mengetahui efek penambahan oats pada formulasi cookies gandum dilihat dari karakteristik fisik dan sensorinya. Enam formulasi campuran tepung gandum dan oats untuk adonan cookies yang digunakan dalam penelitian ini meliputi Kontrol (100\%:0\%), Formulasi 1 (80\%:20\%), Formulasi 2 (60\%:40\%), Formulasi 3 (40\%:60\%), Formulasi 4 (20\%:80\%), dan Formulasi 5 (0\%:100\%). Berdasarkan hasil perhitungan analysis of variance (ANOVA) pada $\alpha=5 \%$, terdapat perbedaan signifikan pada nilai hardness dan work kontrol dan semua variasi formulasi cookies. Dari hasil penelitian juga menunjukkan bahwa semakin menurunnya komposisi tepung gandum dan meningkatnya komposisi oats menyebabkan penurunan nilai hardness dan work. Dari segi warna, penambahan oats justru meningkatkan tingkat kecerahan (L), menurunkan nilai $\mathrm{a}^{*}$ (warna merah), dan meningkatkan nilai $\mathrm{b}^{*}$ (warna kuning) pada cookies. Secara sensori, dibandingkan dengan kontrol,
\end{abstract}


penambahan oats dalam formulasi cookies gandum meningkatkan rating penerimaan untuk parameter warna secara keseluruhan formulasi, rasa untuk Formulasi 2-5, serta overall untuk Formulasi 2 dan 3, sedangkan untuk parameter tekstur, penambahan oats tidak memberikan peningkatan rating penerimaan.

Kata kunci: cookies, gandum, karakteristik fisik, karakteristik sensori, oats

\section{PENDAHULUAN}

Cookies merupakan salah satu produk bakery yang populer karena rasanya, kepraktisannya untuk siap dimakan (readyto-eat) dan kandungan gizinya. Pada perkembangannya, penambahan serat dalam formulasi cookies banyak dipelajari untuk membuat produk cookies fungsional (Bilgiçli et al., 2007; Larrea et al., 2005; Uysal et al., 2007). Pangan fungsional sendiri didefinisikan sebagai produk pangan dan komponen pangan yang dapat menyediakan manfaat kesehatan melebihi manfaat dasar yang terdapat dalam suatu produk pangan (Handa et al., 2012).

Penelitian-penelitian yang telah dilakukan sebelumnya menunjukkan bahwa dengan konsumsi oats memberikan dampak positif terhadap kesehatan, terutama karena kandungan serat pangan ( $\beta$-glukan) dan senyawa-senyawa fenoliknya yang mempunyai aktivitas antioksidan tinggi (Rasane et al., 2013). Serat pangan merupakan salah satu asupan yang penting untuk manusia. Fungsi serat pangan sendiri adalah untuk mengatur laju pencernaan dan laju penyerapan gizi serta berfungsi sebagai subtrat bagi mikroflora dalam usus dan meningkatkan laksasi (Schneeman, 1998), selain itu juga berfungsi untuk menurunkan kolesterol darah, menurunkan tekanan darah, serta mencegah kanker usus besar (Chen et al., 2006; He et al., 2004; Wang et al., 2011).

Di Indonesia, oats sudah mulai banyak dijual dalam berbagai merk produk komersil. Oats sendiri biasanya dikonsumsi oleh populasi dewasa dengan usia 19 tahun ke atas berkisar 6,5\%-11,1\%, sedangkan untuk populasi usia 3 sampai 18 tahun jumlah konsumsinya masih sedikit, berkisar 1,14,6\%. (Musa-Veloso et al., 2016). Melihat potensi cookies yang disukai oleh segala usia, penambahan oats dalam formulasi cookies dimungkinkan untuk meningkatkan jumlah konsumsi oats untuk populasi usia di bawah 19 tahun. Oleh karena itu, penelitian ini bertujuan untuk mengetahui efek penambahan oats pada formulasi cookies gandum dilihat dari karakteristik fisik dan sensorinya.

\section{METODE PELAKSANAAN}

\section{Bahan}

Bahan pembuatan cookies meliputi tepung gandum dan oats. Tepung gandum dibeli dari Fakultas Pertanian dan Bisnis Universitas Kristen Satya Wacana Salatiga, sedangkan oats dibeli dari PT Kobe Boga Utama. Bahan analisis kimia yang digunakan meliputi n-heksana, $\mathrm{H}_{2} \mathrm{SO}_{4}$, dan $\mathrm{NaOH}$.

\section{Alat}

Peralatan yang digunakan untuk pembuatan cookies meliputi mixer (Philips HR1552) dan oven (Bima Jaya). Peralatan analisis yang digunakan meliputi Chromameter (Konika Minolta CR400), Texture Analyzer (Lloyd TA Plus), Spektrofotometer (UV-1280 Shimadzu), IWAKI Soxh-Set-1000, moisture balance (Pioneer MB25), Kjedahl (VELP Scientifica UDK 139).

\section{Metode}

Komposisi bahan serta metode pembuatan cookies merujuk pada metode yang digunakan Suas (2009). Rancangan penelitian dapat dilihat pada Tabel 1 . Analisis yang dilakukan meliputi analisis warna, analisis fisik, analisis sensori, analisis kimia, serta analisis statistik. Analisis warna merujuk pada metode yang dilakukan Altindag et al. (2015) menggunakan chromameter. Analisis fisik merujuk pada 
metode yang digunakan (Kulthe et al., 2014) menggunakan texture analyzer.

Analisis sensori menggunakan uji penerimaan rating kesukaan (Meilgaard, Carr, dan Civille, 2007) dari empat parameter yaitu warna, rasa, tekstur, dan penerimaan overall. Rating yang digunakan adalah rating 5 skala (skala 1 merupakan skala paling tidak disukai sampai skala 5 merupakan skala yang paling disukai). Panelis yang dilibatkan untuk analisis sensori sebanyak 40 panelis tidak terlatih dengan rentang usia remaja (12-18 tahun).

Tabel 1. Rancangan penelitian cookies gandum dengan penambahan oats

\begin{tabular}{cccc}
\hline Formulasi & $\begin{array}{c}\text { Tepung } \\
\text { Gandum }\end{array}$ & $\begin{array}{c}\text { Tepung } \\
\text { Oat }\end{array}$ & $\begin{array}{c}\text { Jumlah } \\
\text { Total }\end{array}$ \\
\hline Kontrol & $100 \%$ & $0 \%$ & \\
1 & $80 \%$ & $20 \%$ & \\
2 & $60 \%$ & $40 \%$ & $100 \%$ \\
3 & $40 \%$ & $60 \%$ & \\
4 & $30 \%$ & $70 \%$ & \\
5 & $0 \%$ & $100 \%$ & \\
\hline
\end{tabular}

Data yang diperoleh dianalisis menggunakan metode analysis of variance (ANOVA) dengan signifikansi 5\% untuk mengetahui adanya pengaruh pada setiap parameter perlakuan. Hasil yang signifikan dari ANOVA kemudian dilanjutkan dengan metode duncan's multiple range test (DMRT) pada signifikansi 5\% untuk menentukan taraf perlakuan yang memberikan perbedaan nyata. Keseluruhan pengujian statistik dibantu software IBM SPSS Statistic 20.

\section{HASIL DAN PEMBAHASAN}

\section{Karakteristik fisik}

Karakteristik tekstur dari cookies gandum berbagai formulasi dapat dilihat pada Tabel 2. Tingkat kekerasan cookies yang tinggi ditunjukkan oleh nilai hardness yang semakin tinggi, sedangkan semakin tinggi nilai work menunjukkan semakin besar upaya untuk mengunyahnya.
Berdasarkan hasil perhitungan analysis of variance (ANOVA) pada $\alpha=5 \%$, terdapat perbedaan signifikan pada nilai hardness dan work kontrol dan semua variasi Formulasi cookies. Nilai hardness dan work tertinggi diperoleh cookies Formulasi 1. Dari data juga diperoleh bahwa semakin menurunnya komposisi tepung gandum dan meningkatnya komposisi oats menyebabkan penurunan nilai hardness dan work.

Berdasarkan uji korelasi Pearson, diperoleh bahwa terdapat korelasi signifikan antara hardness dan work dengan penambahan oats pada cookies gandum dalam penelitian ini. Berdasarkan pengujian tekstur, penambahan persentase oats dalam formulasi cookies menyebabkan adonan tidak homogen dan menyebabkan tekstur akhir yang rapuh karena terdapat perbedaan ukuran partikel dari tepung gandum dan oats. Pada Tabel 2 terlihat bahwa tingkat kekerasan (hardness) nilainya semakin menurun dan cookies menjadi semakin mudah dipatahkan.

Karakteristik warna dari cookies gandung berbagai formulasi dapat dilihat pada Tabel 2, ditunjukkan dengan nilai $\mathrm{L}$, $a^{*}$, dan $b^{*}$. Berdasarkan perhitungan ANOVA pada $\alpha=5 \%$, nilai L (tingkah kecerahan), a* positif (rona warna merah), dan $b^{*}$ positif (rona warna kuning) semua formulasi cookies dalam penelitian ini mempunyai perbedaan yang signifikan. Warna merupakan salah satu karakteristik yang penting untuk mengetahui penerimaan produk oleh konsumen. Tingkat kecerahan (L) cookies gandum pada kontrol sampai Formulasi 5 meningkat. Semakin turun tingkat kecerahan cookies mengindikasikan terjadinya reaksi karamelisasi dan reaksi Maillard pada cookies saat proses baking (Laguna et al., 2011). Pada penelitian ini, penambahan oats justru meningkatkan tingkat kecerahan cookies sehingga terdapat kemungkinan bahwa oats menurunkan laju reaksi karamelisasi dan Maillard pada saat proses baking. 
Tabel 2. Karakteristik fisik cookies gandum dengan penambahan oats

\begin{tabular}{lccccc}
\hline & Hardness $(\boldsymbol{g}$ f) & $\begin{array}{c}\text { Work } \\
(\boldsymbol{k g f} \text {.mm })\end{array}$ & $\mathbf{L}$ & $\mathbf{a}^{*}$ & $\mathbf{b}^{*}$ \\
\hline Kontrol & $3090,49 \pm 398,77^{4}$ & $2,16 \pm 0,77^{2,3}$ & $56,35 \pm 2,51^{1}$ & $7,03 \pm 2,17^{3}$ & $19,23 \pm 1,11^{1}$ \\
Formulasi 1 & $3337,39 \pm 510,83^{4}$ & $3,11 \pm 1,17^{3}$ & $60,58 \pm 2,30^{2,3}$ & $5,15 \pm 0,42^{2}$ & $19,87 \pm 0,75^{1}$ \\
Formulasi 2 & $2352,08 \pm 263,90^{3}$ & $1,93 \pm 1,37^{2,3}$ & $62,74 \pm 2,26^{2,3}$ & $4,27 \pm 0,84^{1,2}$ & $19,91 \pm 1,09^{1}$ \\
Formulasi 3 & $1536,09 \pm 318,32^{2}$ & $1,10 \pm 0,32^{1,2}$ & $62,84 \pm 2,25^{2}$ & $4,29 \pm 0,60^{1,2}$ & $20,62 \pm 1,67^{1,2}$ \\
Formulasi 4 & $440,80 \pm 123,62^{1}$ & $0,54 \pm 0,30^{1}$ & $63,22 \pm 2,23^{3}$ & $3,27 \pm 0,36^{1}$ & $22,74 \pm 1,69^{2}$ \\
Formulasi 5 & $631,80 \pm 156,69^{1}$ & $0,43 \pm 0,25^{1}$ & $68,07 \pm 1,50^{4}$ & $3,36 \pm 0,68^{2}$ & $22,64 \pm 4,50^{2}$ \\
\hline
\end{tabular}

Keterangan: Angka superscript yang berbeda pada kolom yang sama menunjukkan perbedaan yang signifikan $(\alpha=5 \%)$.

Berdasarkan penelitian sebelumnya, peningkatan kecerahan dan warna kuning pada cookies disebabkan oleh meningkatnya juga kandungan serat, protein, serta kandungan polifenol dalam cookies (Jan, Panesar, dan Singh 2018). Pada penelitian ini, peningkatan kandungan serat dikaitkan dengan meningkatnya persentase penambahan oats dalam formulasi cookies. Proses baking saat pembuatan cookies pada umumnya menyebabkan peningkatan pada nilai $a^{*}$ (warna merah) dan nilai $b^{*}$ (warna kuning). Pada penelitian ini, dengan metode baking yang sama pada semua formulasi cookies, terlihat pada Tabel 2, bahwa nilai a* mengalami penurunan dari kontrol sampai Formulasi 5, sedangkan nilai $b^{*}$ mengalami peningkatan.

\section{Karakteristik sensori rating penerimaan cookies}

Hasil cookies gandum berbagai formulasi dapat dilihat pada Gambar 1. Karakteristik sensori dari cookies gandum berbagai formulasi dapat dilihat pada Tabel 3. Cookies diujikan menggunakan uji penerimaan rating kesukaan dengan 5 skala, di mana skala 1 merupakan yang paling tidak disukai sampai skala 5 merupakan yang paling disukai. Dari perhitungan ANOVA $(\alpha=5 \%)$ terhadap setiap parameter sensori yang diujikan (warna, rasa, tekstur, dan overall) pada cookies gandum dengan penambahan oats, terdapat tiga parameter yang mempunyai perbedaan signifikan yaitu parameter warna, tekstur, dan overall, sedangkan untuk parameter rasa tidak berbeda signifikan.
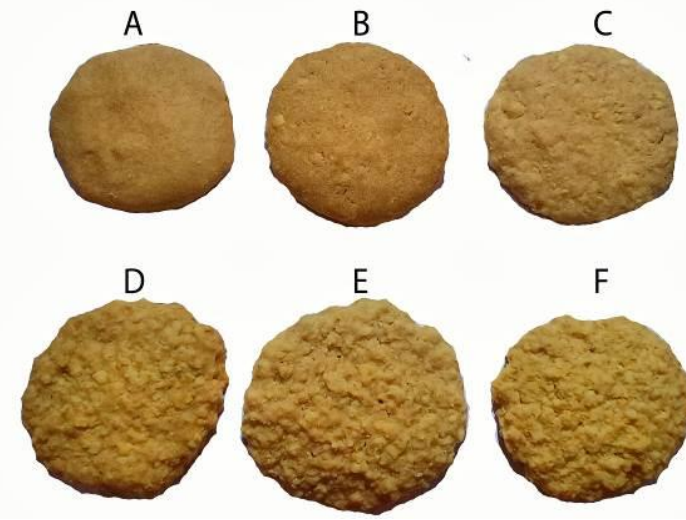

$\mathrm{F}$

Gambar 1. Hasil cookies gandum berbagai formulasi

Keterangan:

A. Kontrol; B. Formulasi 1; C. Formulasi 2;

D. Formulasi 3; E. Formulasi 4; F. Formulasi 5

Cookies gandum yang memperoleh rating penerimaan tertinggi secara overall, termasuk rating penerimaan tertinggi untuk parameter warna serta rasa adalah cookies dengan Formulasi 2. Hasil dari uji sensori cookies gandum dengan penambahan oats menunjukkan bahwa rating parameter penerimaan secara overall semua formulasi cookies dalam penelitian ini masih bisa diterima dengan rentang penerimaan netral sampai suka. Dari Tabel 3 juga dapat dilihat, bahwa dibandingkan dengan kontrol, penambahan oats dalam formulasi cookies gandum meningkatkan rating penerimaan untuk parameter warna secara keseluruhan formulasi, rasa untuk Formulasi 2-5, serta overall untuk Formulasi 2 dan 3, sedangkan untuk parameter tekstur, penambahan oats tidak memberikan peningkatan rating penerimaan. 
Tabel 3. Hasil uji sensori penerimaan rating kesukaan

\begin{tabular}{lllll}
\hline & Warna & Rasa & Tekstur & Overall \\
\hline Kontrol & $3,08 \pm 1,04^{2}$ & $3,34 \pm 0,87^{1}$ & $3,48 \pm 0,81^{1}$ & $3,48 \pm 0,76^{2}$ \\
Formulasi 1 & $3,34 \pm 0,88^{1,2}$ & $3,24 \pm 0,72^{1}$ & $3,20 \pm 0,73^{1}$ & $3,28 \pm 0,76^{2}$ \\
Formulasi 2 & $3,50 \pm 0,85^{1}$ & $3,62 \pm 0,64^{1}$ & $3.28 \pm 0,73^{1}$ & $3,70 \pm 0,61^{1}$ \\
Formulasi 3 & $3,24 \pm 0,76^{1,2}$ & $3,54 \pm 0.93^{1}$ & $3,3 \pm 0,76^{1}$ & $3,64 \pm 0,63^{1}$ \\
Formulasi 4 & $3,28 \pm 1,20^{1,2}$ & $3,40 \pm 0,95^{1}$ & $2,86 \pm 0,76^{2}$ & $3,20 \pm 0,95^{2}$ \\
Formulasi 5 & $3,08 \pm 0,92^{2}$ & $3,36 \pm 1,08^{1}$ & $2,72 \pm 1,05^{2}$ & $3,16 \pm 0,84^{2}$ \\
\hline
\end{tabular}

Keterangan: Angka superscript yang berbeda pada kolom yang sama menunjukkan perbedaan yang signifikan $(\alpha=5 \%)$

\section{KESIMPULAN}

Berdasarkan hasil perhitungan analysis of variance (ANOVA) pada $\alpha=5 \%$, terdapat perbedaan signifikan pada nilai hardness dan work kontrol dan semua variasi formulasi cookies. Semakin menurunnya komposisi tepung gandum dan meningkatnya komposisi oats menyebabkan penurunan nilai hardness dan work. Dari segi warna, penambahan oats justru meningkatkan tingkat kecerahan (L), menurunkan nilai a* (warna merah), dan meningkatkan nilai $b^{*}$ (warna kuning) pada cookies. Secara sensori, dibandingkan dengan kontrol, penambahan oats dalam formulasi cookies gandum meningkatkan rating penerimaan untuk parameter warna secara keseluruhan formulasi, rasa untuk Formulasi 2-5, serta overall untuk Formulasi 2 dan 3, sedangkan untuk parameter tekstur, penambahan oats tidak memberikan peningkatan rating penerimaan.

\section{DAFTAR PUSTAKA}

Altindag, G., Certel, M., Erem, F., \& Ilknur Konak, Ü. (2015). Quality characteristics of gluten-free cookies made of buckwheat, corn, and rice flour with/without transglutaminase. Food Science and Technology International, 21(3), 213-220. https://doi.org/10.1177/10820132145 25428

Bilgiçli, N., Ibanoğlu, Ş., \& Herken, E. N. (2007). Effect of dietary fibre addition on the selected nutritional properties of cookies. Journal of Food Engineering, 78(1), 86-89. https://doi.org/10.1016/j.jfoodeng.20 05.09.009

Chen, J., He, J., Wildman, R. P., Reynolds, K., Streiffer, R. H., \& Whelton, P. K. (2006). A randomized controlled trial of dietary fiber intake on serum lipids. European Journal of Clinical Nutrition, 60(1), 62-68. https://doi.org/10.1038/sj.ejcn.16022 68

Handa, C., Goomer, S., \& Siddhu, A. (2012). Physicochemical properties and sensory evaluation of fructoligosaccharide enriched cookies. Journal of Food Science and Technology, 49(2), 192-199. https://doi.org/10.1007/s13197-0110277-4

He, J., Streiffer, R. H., Muntner, P., KrouselWood, M. A., \& Whelton, P. K. (2004). Effect of dietary fiber intake on blood pressure: A randomized, double-blind, placebo-controlled trial. Journal of Hypertension, 22(1), 73-80.

https://doi.org/10.1097/00004872200401000-00015

Jan, K. N., Panesar, P. S., \& Singh, S. (2018). Textural, in vitro antioxidant activity and sensory characteristics of cookies made from blends of wheatquinoa grown in India. Journal of Food Processing and Preservation, 42(3). https://doi.org/10.1111/jfpp.13542

Kulthe, A. A., Pawar, V. D., Kotecha, P. M., Chavan, U. D., \& Bansode, V. V. (2014). Development of high protein and low calorie cookies. Journal of Food Science and Technology, 51(1), 
153-157.

https://doi.org/10.1007/s13197-0110465-2

Laguna, L., Salvador, A., Sanz, T., \& Fiszman, S. M. (2011). Performance of a resistant starch rich ingredient in the baking and eating quality of short-dough biscuits. LWT - Food Science and Technology, 44(3), 737746.

https://doi.org/10.1016/j.lwt.2010.05. 034

Larrea, M. A., Chang, Y. K., \& MartinezBustos, F. (2005). Some functional properties of extruded orange pulp and its effect on the quality of cookies. LWT - Food Science and Technology, 38(3), 213-220. https://doi.org/10.1016/j.lwt.2004.05. 014

Meilgaard, M. C., Carr, B. T., \& Civille, G. V. (2007). Sensory evaluation techniques (Fourth edition). CRC press.

https://doi.org/doi:10.1201/97814398 32271.fmatt

Musa-Veloso, K., Fallah, S., O’Shea, M., \& Chu, Y. F. (2016). Assessment of intakes and patterns of cooked oatmeal consumption in the U.S. using data from the national health and nutrition examination surveys. Nutrients, $8(8)$. https://doi.org/10.3390/nu8080503

Rasane, P., Jha, A., Sabikhi, L., Kumar, A., \& Unnikrishnan, V. S. (2013).
Nutritional advantages of oats and opportunities for its processing as value added foods $-\mathrm{A}$ review. Journal of Food Science and Technology, 52(2), 662-675. https://doi.org/10.1007/s13197-0131072-1

Schneeman, B. O. (1998). Dietary fiber and gastrointestinal function. Nutrition Research, 18(4), 625-632. https://doi.org/10.1016/S02715317(98)00049-9

Suas, M. (2009). Advanced bread and pastry: A professional approach. New York: Delmar Cengage Learning.

Uysal, H., Bilgiçli, N., Elgün, A., Ibanoğlu, Ş., Herken, E. N., \& Kürşat Demir, M. (2007). Effect of dietary fibre and xylanase enzyme addition on the selected properties of wire-cut cookies. Journal of Food Engineering, 78(3), 1074-1078. https://doi.org/10.1016/j.jfoodeng.20 05.12.019

Wang, H. C., Hung, C. H., Hsu, J. D., Yang, M. Y., Wang, S. J., \& Wang, C. J. (2011). Inhibitory effect of whole oat on aberrant crypt foci formation and colon tumor growth in ICR and BALB/c mice. Journal of Cereal Science, 53(1), 73-77. https://doi.org/10.1016/j.jcs.2010.09. 009 